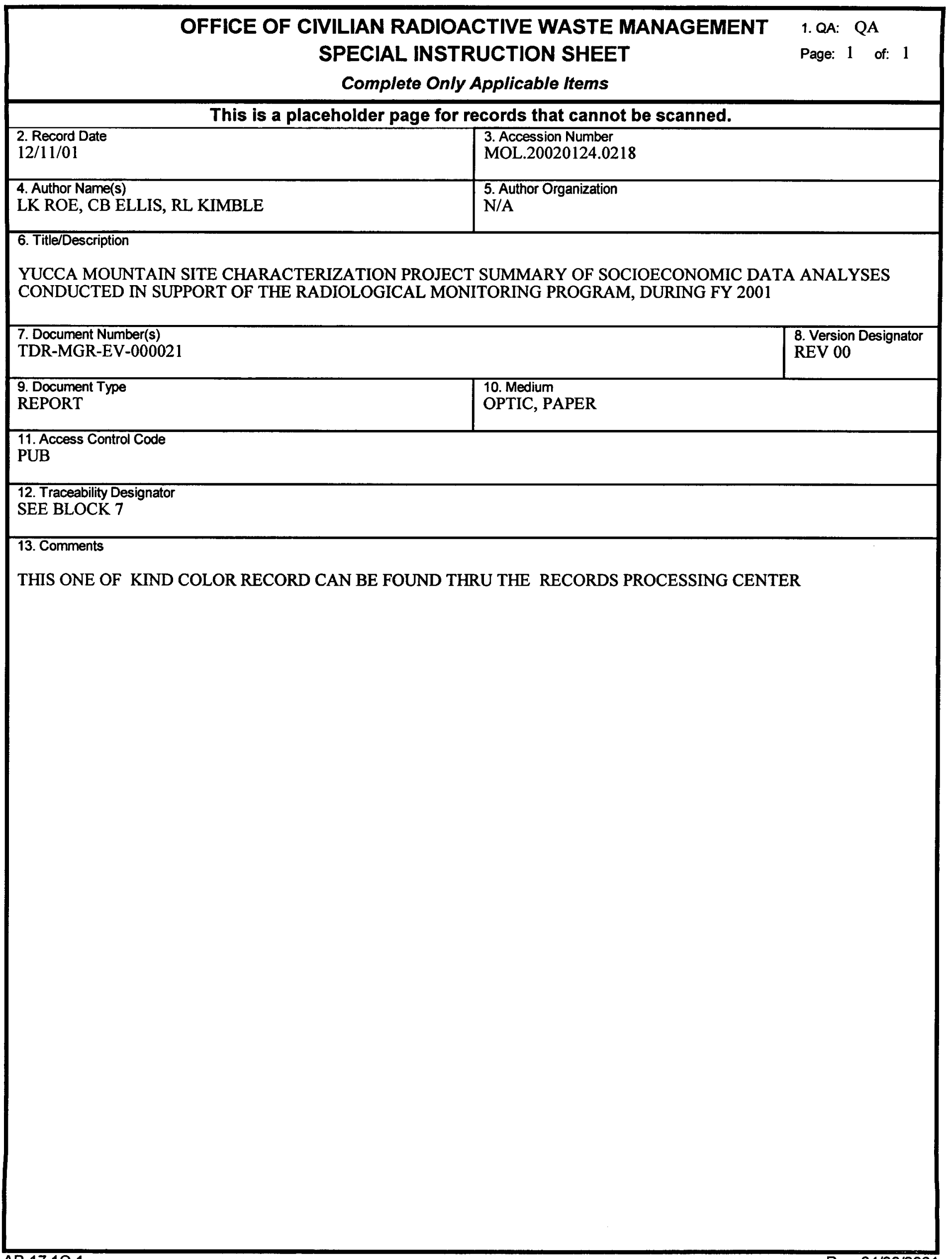


QA: QA

TDR-MGR-EV-000021 Rev 00

December 2001

\section{Yucca Mountain Site Characterization Project Summary of Socioeconomic Data Analyses Conducted in Support of the Radiological Monitoring Program, During FY 2001}

Prepared for:

U.S. Department of Energy

Yucca Mountain Site Characterization Office

P.O. Box 30307

North Las Vegas, Nevada 89036-0307

Prepared by:

Bechtel SAIC Company, LLC

1180 Town Center Drive

Las Vegas, Nevada 89144

Under Contract Number

DE-AC08-01RW12101 


\section{DISCLAIMER}

This report was prepared as an account of work sponsored by an agency of the United States Government. Neither the United States Government nor any agency thereof, nor any of their employees, nor any of their contractors, subcontractors or their employees, makes any warranty, express or implied, or assumes any legal liability or responsibility for the accuracy, completeness, or any third party's use or the results of such use of any information, apparatus, product, or process disclosed, or represents that its use would not infringe privately owned rights. Reference herein to any specific commercial product, process, or service by trade name, trademark, manufacturer, or otherwise, does not necessarily constitute or imply its endorsement, recommendation, or favoring by the United States Government or any agency thereof or its contractors or subcontractors. The views and opinions of authors expressed herein do not necessarily state or reflect those of the United States Government or any agency thereof. 
Yucca Mountain Site Characterization Project

Summary of Socioeconomic Data Analyses

Conducted in Support of the Radiological Monitoring

Program, During FY 2001

Prepared by:

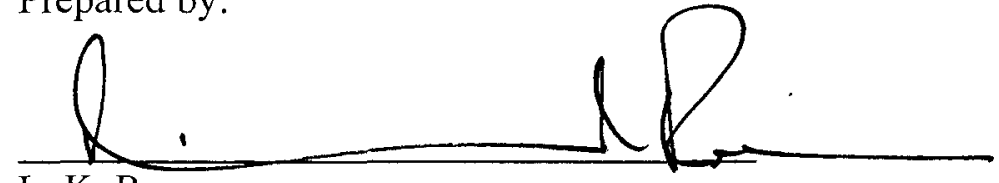

L. K. Roe

Environmental Scientist, Regional Data Analysis

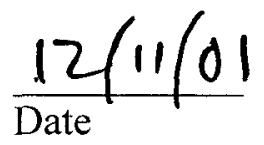

Checked by:

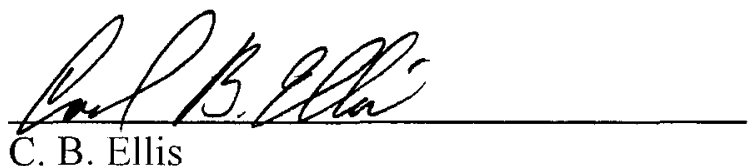

C. B. Ellis

Environmental Scientist, Regional Data Analysis

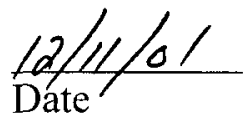

Date

Approved by:

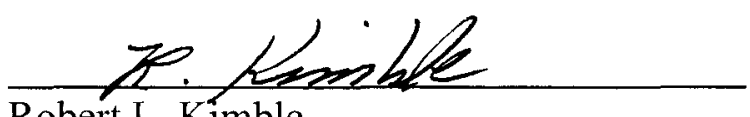

Robert L. Kimble

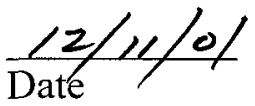

Manager, Regional Data Analysis 


\section{EXECUTIVE SUMMARY}

This report is a summary of socioeconomic data analyses conducted in support of the Radiological Monitoring Program during fiscal year 2001. Socioeconomic data contained in this report include estimates for the years 2000 and 2001 of the resident population in the vicinity of Yucca Mountain. The estimates presented in this report are based on selected Census 2000 statistics, and housing and population data that were acquired and developed in accordance with LP-RS-001Q-M\&O, Scientific Investigation of Economic, Demographic, and Agricultural Characteristics in the Vicinity of Yucca Mountain.

The study area from which data were collected is delineated by a radial grid, consisting of 160 grid cells, that is suitable for evaluating the pathways and potential impacts of a release of radioactive materials to the environment within a distance of 84 kilometers from Yucca Mountain. Data are presented in a tabular format by the county, state, area, and grid cell in which housing units, households, and resident population are located. Also included is a visual representation of the distribution of the 2000 residential populations within the study area, showing Census 2000 geography, county boundaries, and taxing district boundaries for selected communities. 


\section{INTENTIONALLY LEFT BLANK}




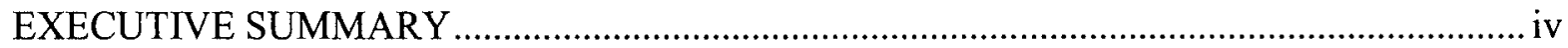

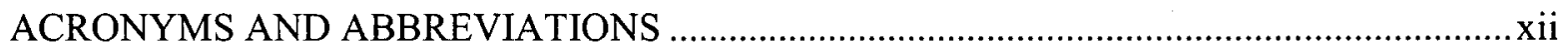

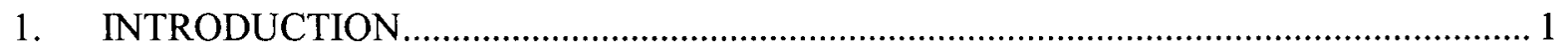

1.1 BACKGROUND..........................................................................................

1.2 METHODOLOGICAL AND DATA IMPROVEMENTS ………............................ 2

1.3 CHANGES TO THE PREVIOUS REPORT ………........................................... 2

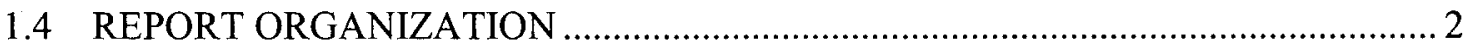

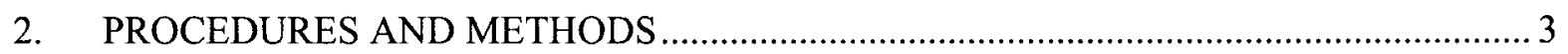

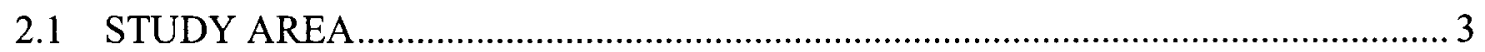

2.2 DATA SOURCES AND DATA COLLECTION METHODS..................................... 3

2.2.1 Direct Windshield Survey ......................................................................... 3

2.2.2 Electric Utility Administrative Records ………….................................... 4

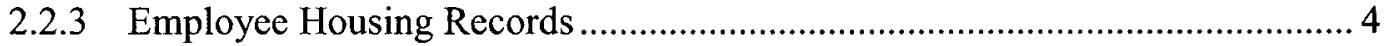

2.2.4 Bureau of the Census............................................................................... 4

2.3 ESTIMATES OF TOTAL POPULATION …………............................................ 4

2.3.1 Number of Households........................................................................... 5

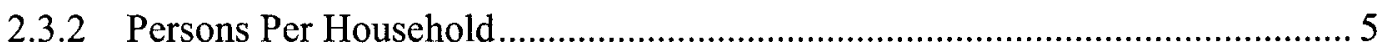

2.3.3 Persons Living in Group Quarters............................................................ 5

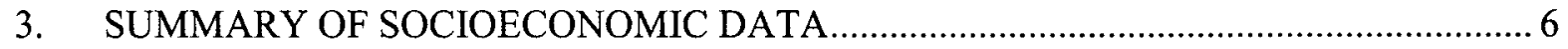

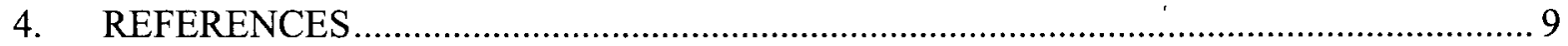

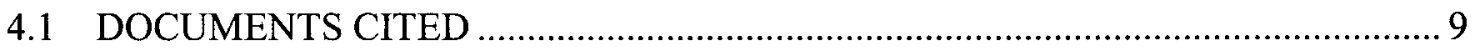

4.2 CODES, STANDARDS, REGULATIONS, AND PROCEDURES ……………......... 9

4.3 SOURCE DATA, LISTED BY DATA TRACKING NUMBER ………................ 10

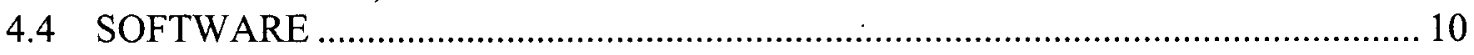

APPENDIX A - DOCUMENTATION OF THE USE OF COMMERCIAL OFF-THE-SHELF

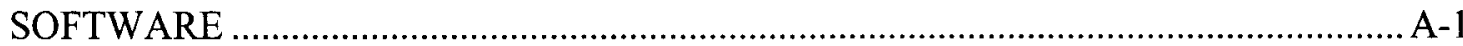


INTENTIONALLY LEFT BLANK 


\section{FIGURES}

Page

1. 2000 Population Distribution Within the $84 \mathrm{~km}$ Radiological Monitoring Grid (Census 2000 Geography) ....................................................................................... 8 
INTENTIONALLY LEFT BLANK

December 2001 


\section{TABLES}

\section{Page}

1. 2000 and 2001 Estimates of the Resident Population Located Within the 84-Kilometer Radiological Monitoring Grid. 
INTENTIONALLY LEFT BLANK 


\section{ACRONYMS AND ABBREVIATIONS}

$\begin{array}{ll}\text { BG } & \text { block group } \\ \text { COTS } & \begin{array}{l}\text { commercial off-the-shelf } \\ \text { CRWMS }\end{array} \\ \text { DVNilian Radioactive Waste Management System } \\ \text { FY } & \text { Death Valley National Park } \\ \text { GIS } & \text { fiscal year } \\ \text { GQ } & \begin{array}{l}\text { Geographic Information System } \\ \text { group quarters }\end{array} \\ \text { H } & \text { number of households } \\ \text { HU } & \text { housing unit } \\ \text { km } & \text { kilometer } \\ \text { M\&O } & \text { Management and Operating Contractor } \\ \text { PPH } & \text { persons per household } \\ \text { RadMP } & \text { Radiological Monitoring Program } \\ \text { SQL } & \text { software query language } \\ \text { WS } & \text { windshield survey }\end{array}$


INTENTIONALLY LEFT BLANK 


\section{INTRODUCTION}

This document is the eleventh in a series of annual reports that present site-specific socioeconomic data compiled for the Radiological Monitoring Program (RadMP). Data compiled for the RadMP are an integral component of studies conducted in support of the Environmental Impact Statement, the Total System Performance Assessment, Site Recommendation, and License Application. Socioeconomic data contained in this report include estimates for the years 2000 and 2001 of the resident population in the vicinity of Yucca Mountain. The estimates presented in this report are based on Bureau of the Census, Census 2000 information, and include estimates of the distribution of the 2000 and 2001 residential population by Census 2000 geography.

Socioeconomic support for the RadMP performed by Bechtel SAIC Company, LLC Regional Data Analysis personnel is subject to the requirements in Quality Assurance Requirements and Description, DOE/RW-0333P (DOE 2000). Quality-affecting activities include the collection, analysis, and reporting of socioeconomic data suitable for use in the RadMP. The Technical Work Plan Socioeconomic Support for the Radiological Monitoring Program (RadMP) (CRWMS M\&O 2000a) was prepared in accordance with AP-2.21Q, Quality Determinations And Planning For Scientific, Engineering, And Regulatory Compliance Activities. The requirements of this plan were addressed during the collection and analysis of data, including implementation of LP-RS-001Q-M\&O, Scientific Investigation of Economic, Demographic, and Agricultural Characteristics in the Vicinity of Yucca Mountain. This procedure supercedes NWI-RSD-002Q, Scientific investigation of Economic, Demographic, and Agricultural Characteristics in the Vicinity of Yucca Mountain originally referenced in the plan. This report was prepared in accordance with AP-3.11Q, Technical Reports.

\subsection{BACKGROUND}

Data requirements for the RadMP are based on the "Energy: General Guidelines for the Recommendation of Sites for Nuclear Waste Repositories" (10 CFR 960). These guidelines specify the socioeconomic data necessary for evaluating the suitability of the Yucca Mountain site for development as a repository, which are to include a description of the population density and distribution of the region surrounding the site.

RadMP data also must be suitable for input to analyses conducted in support of Total System Performance Assessment, Site Recommendation, and License Application. To evaluate potential radiation exposure, performance assessments use biosphere models that describe the pathways by which individuals might receive radiation doses. Area-specific population data are required to estimate potential radiation exposure to the resident population within approximately 50 miles of the Yucca Mountain site. The specifications for these analyses are determined, in part, by technical guidelines set forth by the Nuclear Regulatory Commission in Regulatory Guide 4.2, Preparation of Environmental Reports for Nuclear Power Stations. 


\subsection{METHODOLOGICAL AND DATA IMPROVEMENTS}

Improvements were made that contribute to the reliability of information collected using the windshield survey (WS) method of data collection. During 2001, County Assessor parcel maps were used to assist in the identification of streets, tracts, and potential housing unit (HU) locations in the areas of Cold Creek and Indian Springs. As a result, the block boundaries for Cold Creek, and portions of Indian Springs, were remapped to allow for consistency in recording future WS data.

Improvements also were made to the method of data collection in areas of Death Valley National Park (DVNP) in California where resort employees and their families represent a large component of the resident population. These areas include Furnace Creek Inn, Furnace Creek Resort, Scotty's Castle, and Stovepipe Wells Village. The WS method of data collection (previously used in these areas) was found to be ineffective in 2001 because of the recent construction and occupancy of multi-unit employee housing. The WS method of data collection was replaced by acquiring data directly from a DVNP management company (MO0111GSC01150.000). Information provided by DVNP management identifies the actual number of persons residing at the various resort locations. This significantly upgrades the validity of estimates reported for Inyo County, California.

\subsection{CHANGES TO THE PREVIOUS REPORT}

A change was made in the method used to estimate the number of households that resulted in a set of revised 2000 estimates for resident population that are higher than the values previously reported in Table 1 of Yucca Mountain Site Characterization Project Summary of Socioeconomic Data Analyses Conducted in Support of the Radiological Monitoring Program, During FY 2000 (CRWMS M\&O 2000b). This change involves the method used to process data acquired from electric utility administrative records. Previously, the number of households (occupied housing units) was defined as the number of "active" residential electric utility accounts multiplied by the occupancy rate reported by the Bureau of the Census. The estimates in this report are based on the actual number of "active" residential electric utility accounts.

While conducting the 2001 windshield surveys, field verification of the 2000 status of HUs was performed, and HU location identifiers associated with the 2000 windshield surveys were reassigned to coincide with 2001 block boundaries. In cases where a HU was either missed during the 2000 survey, or the status or location was recorded incorrectly, corrections were noted on the Data Collection Log (MO0111GSC01120.000).

\subsection{REPORT ORGANIZATION}

The following section of this document (Section 2) provides a description of the procedures and methods used to develop estimates for the years 2000 and 2001 of the resident population within an 84 kilometer $(\mathrm{km})$ radius of Yucca Mountain. A summary of these data is presented in the third section. References for this document are shown in Section 4. 


\section{PROCEDURES AND METHODS}

This section provides a description of the study area from which data were collected, data sources and data collection techniques, and the method used to calculate population estimates. The software and Geographic Information System (GIS) coverages used to identify the distribution of occupied HU locations within the study area also are identified in this section. A detailed account of the use of commercial off-the-shelf (COTS) software to process and organize information for this report, and the methods used to control the electronic management of data, is provided in Appendix A, Documentation of the Use of Commercial Off-The-Shelf Software.

\subsection{STUDY AREA}

The study area consists of a radial grid that is suitable for evaluating the pathways and potential impacts of a release of radioactive materials to the environment within a distance of $84 \mathrm{~km}$ of Yucca Mountain. This radial grid was developed as a GIS coverage (MO0110COV01122.000) using Arc/Info software (CRWMS M\&O 2000c) in accordance with AP-3.12Q, Calculations. The study area, referred to as the $84-\mathrm{km}$ RadMP Grid, is centered on Nevada State Plane coordinates Northing 765621.5, and Easting 570433.6, which is on the eastern side of Exile Hill at the Yucca Mountain site. The North Portal Pad is located over this point. The 84-km RadMP Grid consists of 160 cells formed by 10 concentric rings and 16 evenly-spaced sections (22.5 degrees each) radiating from the center. The cell labels are derived from a concatenation of the numbering system of the rings and sections. The 16 sections are numbered counterclockwise beginning with the section directly north. Example: Ring 6 and section $4=$ cell 604 . The dimensions of this study area are based, in part, on the technical guidelines set forth by the Nuclear Regulatory Commission in Regulatory Guide 4.2, Preparation of Environmental Reports for Nuclear Power Stations.

\subsection{DATA SOURCES AND DATA COLLECTION METHODS}

The information presented in this report includes estimates for the years 2000 and 2001 of the resident population located within the 84-km RadMP Grid. These estimates are based on selected Census 2000 statistics, and housing and population data that were acquired and developed in accordance with LP-RS-001Q-M\&O, Scientific Investigation of Economic, Demographic, and Agricultural Characteristics in the Vicinity of Yucca Mountain. Each data source used in this analysis is identified below, including a description of the data and the locations from which data were acquired.

\subsubsection{Direct Windshield Survey}

The WS method of data collection (observations made from a motorized vehicle) was used in 2001 to acquire the location and occupancy status of HUs in Cold Creek, Indian Springs, Cactus Springs, and Johnnie (in Nevada); and Timbisha Village, Park Village, Ryan, Death Valley Junction, and Stewart Valley (in California). In 2000, the WS method also was used in Furnace Creek, Scotty's Castle, and Stovepipe Wells (in California). The original source of 2000 and 2001 WS data used in this report is a set of data collection logs (MO0111GSC01120.000). 


\subsubsection{Electric Utility Administrative Records}

Data acquired from electric utility administrative records includes the number and location of active residential meters. The areas in Nevada for which electric utility data are used as the source of housing information include Amargosa Valley, Ash Meadows, Beatty, Crystal, Lathrop Wells, Pahrump, Rhyolite, Stateline, and Stewart Valley. Utility data used to compile the information in this report were acquired in 2000 (MO0009GISVEA13.002) and in 2001 (MO0111GSC01148.000).

\subsubsection{Employee Housing Records}

Data for 2001 were acquired from the DVNP management company. These data include the actual number of persons that reside at Furnace Creek, Scotty's Castle, and Stovepipe Wells Village in Inyo County, California (MO0111GSC01150.000). In 2000, data were acquired for these areas using the WS method of data collection.

\subsubsection{Bureau of the Census}

Bureau of the Census data include block group (BG) information from four census tables: P1. Total Population; P15. Households; P17. Average Household Size; and P37. Group Quarters Population By Group Quarters Type. The BG level of census geography is a subdivision of a census tract that contains a cluster of census blocks. Census tracts are subdivisions of counties that are designed to be relatively homogeneous with respect to population characteristics, economic status, and living conditions. Total population includes all persons living in households and group quarters. A household includes all the people who occupy a HU as their usual place of residence; the number of households is equal to the count of occupied HUs. Average household size is the total number of persons living in households divided by the number of households. Group quarters are places where people live or stay other than the usual HU (house, apartment, or mobile home). Examples of group quarters include nursing homes, hospitals or wards for chronically ill patients, hospices, prison wards, military barracks, and group homes (Bureau of the Census 2001).

Table P37. Group Quarters Population by Group Quarters Type is the source for the number of persons living in group quarters in the Nevada part of the study area. Three census BGs located within the $84-\mathrm{km}$ RadMP Grid were identified as having a group quarters population. Census block-level geography for the three blocks in which the group quarters populations are located was used to determine the location of the group quarters population within the study area. These locations include Block 1104, BG 1, Census Tract 9804.01 (in Grid Cell 1010); Block 2000, BG 2, Census Tract 9804.01 (in Grid Cell 910); and Block 1145, BG 1, Census Tract 9804.03 (in Grid Cell 1010).

\subsection{ESTIMATIONS OF TOTAL POPULATION}

The housing unit method was used to calculate population estimates for all areas of the 84-km RadMP Grid. The basis for this method is that the population of any given geographic area is equal to the number of households $(\mathrm{H})$ times the average number of persons per household 
(PPH), plus the number of persons living in group quarters (GQ) (Smith 1986):

$$
\text { Population }=\left(\mathrm{H}^{*} \mathrm{PPH}\right)+\mathrm{GQ}
$$

A description of each component of the housing unit method and the data sources and definitions used in this particular application to estimate the value of $\mathrm{H}, \mathrm{PPH}$, and GQ are provided below.

\subsubsection{Number of Households}

$\mathrm{H}$ is equal to the count of occupied HUs. In this application, the value of $\mathrm{H}$ is defined in terms of the source of the information and by location. In the areas where the WS method of data collection was used, $\mathrm{H}$ is equal to the number of occupied HUs, based on direct observation. For all other areas, $\mathrm{H}$ is equal to the number of "active" residential electric utility accounts.

\subsubsection{Persons Per Household}

PPH is the number of persons divided by the number of households. The value of PPH used in this application is equal to the average household size reported in Census 2000 Table P17. Average Household Size (Bureau of the Census 2001), for the tract and BG in which each household is located.

\subsubsection{Persons Living in Group Quarters}

GQ include places where people live or stay other than the usual house, apartment, or mobile home. In this application, GQ in Inyo County is equal to the total number of persons residing in employee housing complexes, as reported by the DVNP management company (MO0111GSC01150.000). For the remainder of the study area, GQ is equal to the total group quarters population reported in the Census 2000 in Table P37. Group Quarters Population by Group Quarters Type (Bureau of the Census 2001). Section 2.2.4 of this report identifies the number and location of Census 2000 blocks in the Nevada part of the study area having a group quarters population. 


\section{SUMMARY OF SOCIOECONOMIC DATA}

Estimates, for the years 2000 and 2001, of the resident population located within the 84-km RadMP Grid, are presented in Table 1. Data are organized in this table by the county, state, area, and grid cell in which the resident population are located. Figure 1 provides a visual representation of the distribution of residential housing, and therefore, the residential population, within the 84-km RadMP Grid. This figure includes Census 2000 geography (tracts and BG boundaries), county boundaries, and taxing district boundaries for selected communities.

The information reported in this section is not an exhaustive account of the resident population located within the 84-km RadMP Grid. The findings are simply descriptive, no inferences or conclusions are presented in this report, and there are no particular restrictions on the use of these data. 
Table 1. 2000 and 2001 Estimates of the Resident Population Located Within the 84-Kilometer Radiological Monitoring Grid ${ }^{\mathrm{a}, \mathrm{b}}$

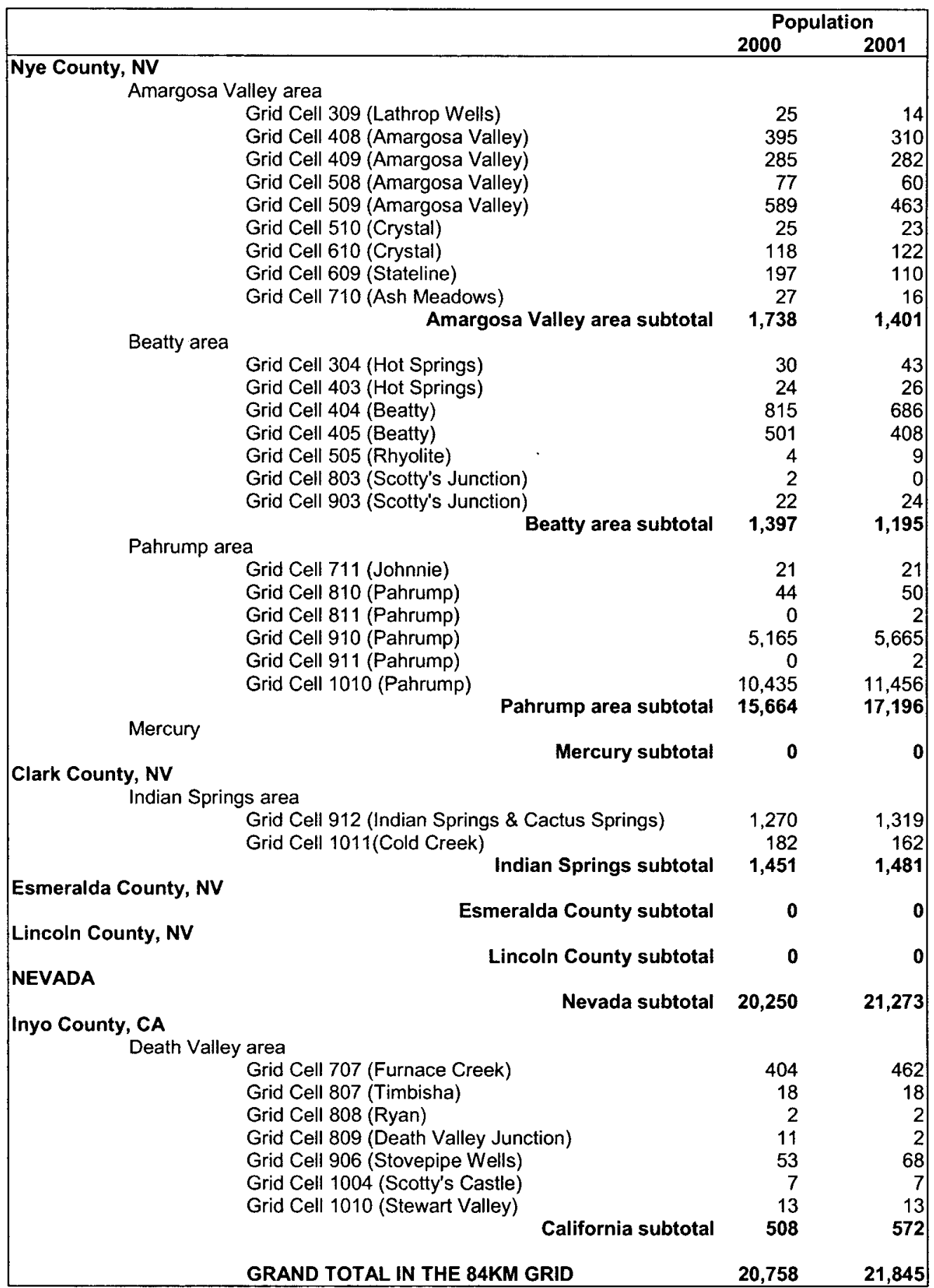

NOTES: ${ }^{a}$ Appendix A, Documentation of the Use of Commercial Off-The-Shelf Software, provides a detailed account of the process and data (including all data tracking numbers) used to develop estimates.

${ }^{b}$ Figures reported in this table have been rounded, therefore, they may not add to the totals and subtotals for the table. 

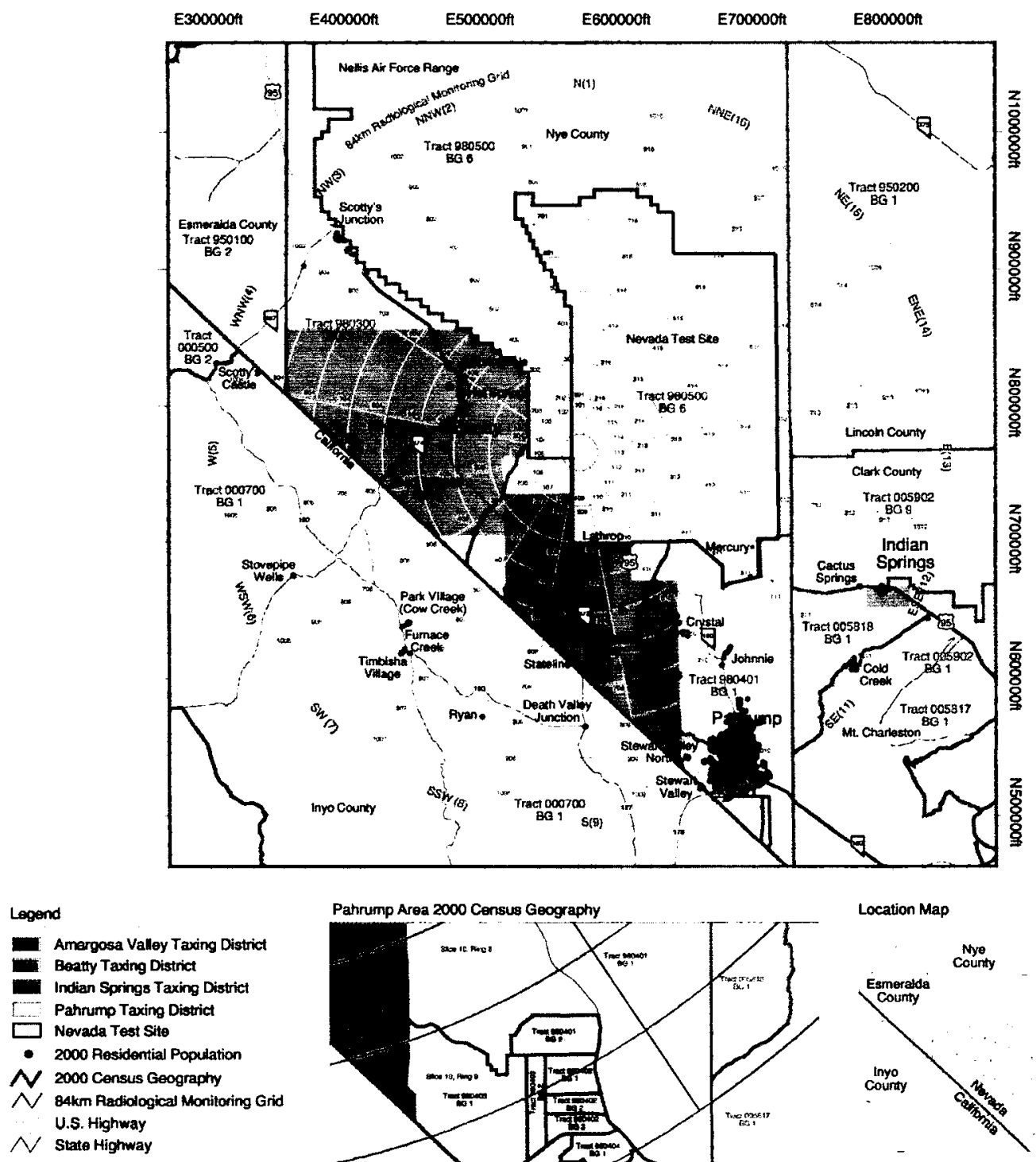

Location Map

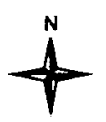

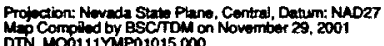
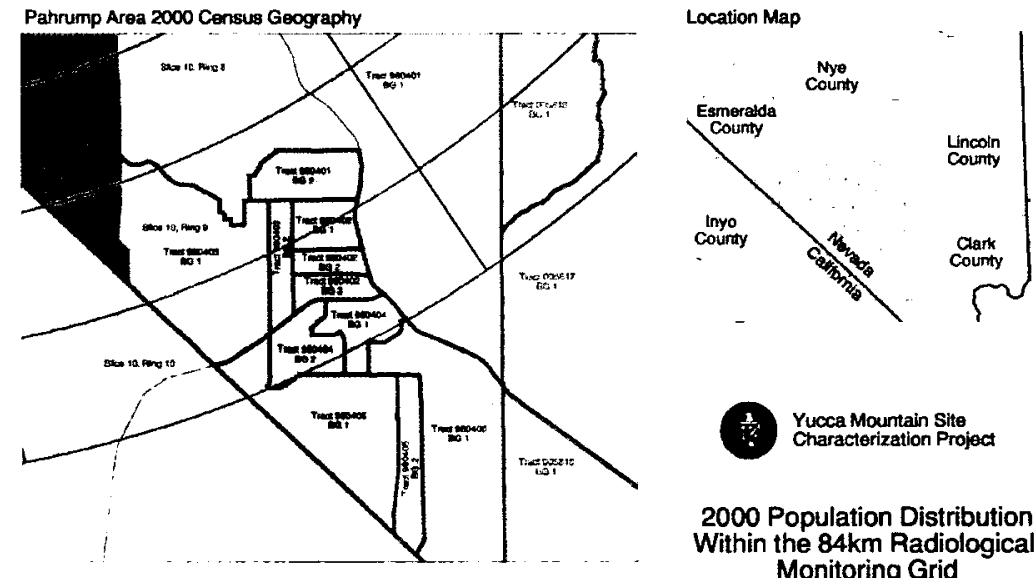
Within the 84km Radiologica Monitoring Grid

(2000 Census Geography)

Figure 1. 2000 Population Distribution Within the $84 \mathrm{~km}$ Radiological Monitoring Grid (Census 2000 Geography) 


\section{REFERENCES}

\subsection{DOCUMENTS CITED}

CRWMS M\&O 2000a. Technical Work Plan Socioeconomic Support for the Radiological Monitoring Program (RadMP). TWP-MGR-MD-000003, REV 00. Las Vegas, Nevada. CRWMS M\&O. ACC: MOL.20001005.0002.

CRWMS M\&O 2000b. Yucca Mountain Site Characterization Project: Summary of Socioeconomic Data Analyses Conducted in Support of the Radiological Monitoring Program, During FY 2000. TDR-MGR-EV-000013 REV 00. Las Vegas, Nevada: CRWMS M\&O. ACC: MOL.20010321.0002.

Smith, S.K. 1986. "A Review and Evaluation of the Housing Unit Method of Population Estimation." Journal of the American Statistical Association, 81, (394), 287-296. [Washington, D.C.]: American Statistical Association. TIC: 249009

\subsection{CODES, STANDARDS, REGULATIONS, AND PROCEDURES}

10 CFR 960. Energy: General Guidelines for the Recommendation of Sites for Nuclear Waste Repositories. Readily available.

AP-2.21Q, Quality Determinations and Planning for Scientific, Engineering, And Regulatory Compliance Activities. Washington, D.C.: U.S. Department of Energy, Office of Civilian Radioactive Waste Management. ACC: MOL.20000802.0003.

AP-3.11Q, Technical Reports. Washington, D.C.: U.S. Department of Energy, Office of Civilian Radioactive Waste Management. ACC: MOL.20001026.0083.

AP-3.12Q, Calculations, D.C.: U.S. Department of Energy, Office of Civilian Radioactive Waste Management. ACC: MOL.20001026.0084.

AP-SI.1Q, Software Management. Washington, D.C.: U.S. Department of Energy, Office of Civilian Radioactive Waste Management. ACC: MOL.20001019.0023.

AP-SV.1Q, Control of the Electronic Management of Data. Washington, D.C.: U.S. Department of Energy, Office of Civilian Radioactive Waste Management. ACC: MOL.20000831.0065.

DOE (U.S. Department of Energy) 2000. Quality Assurance Requirements and Description. DOE/RW-0333P, Rev. 10. Washington, D.C.: U.S. Department of Energy, Office of Civilian Radioactive Waste Management. ACC: MOL.20000427.0422. 
LP-RS-001Q-M\&O, Rev. 0. Scientific Investigation of Economic, Demographic, and Agricultural Characteristics in the Vicinity of Yucca Mountain. Office of Civilian Radioactive Waste Management. ACC: MOL.19990517.0135.

Regulatory Guide 4.2, Rev. 2. 1976. Preparation of Environmental Reports for Nuclear Power Stations. Washington, D.C.: U.S. Nuclear Regulatory Commission. Readily Available.

\subsection{SOURCE DATA, LISTED BY DATA TRACKING NUMBER}

Bureau of the Census 2001. Census 2000 Summary File 1 (ASCII) 2000, Census of Population and Housing, California, Montana, Nebraska, Nevada, New Hampshire, New Jersey, and New Mexico. Washington, D.C.: Bureau of the Census. TIC: 251242.

MO0009GISVEA13.002. VEA_WS DATA. Submittal date: 09/29/2000.

MO0107COV01066.000. Coverage: BLKGRP2KS. Submittal date: 07/24/2001.

MO0110COV01122.000. Coverage: RADGRID2U. Submittal date: 10/17/2001.

MO0111COV01120.000. Coverage: RADHAUS3. Submittal date: 11/05/2001.

MO0111GSC01120.000. WS Data Collection Logs. Submittal date: 11/01/2001.

MO0111GSC01148.000. LINDAROE.EXE. Submittal date: 11/1/2001.

MO0111GSC01150.000. Death Valley National Park Residential Population Data for 2001. Submittal date: $11 / 01 / 2001$.

MO0111GSC01153.000. 00-01 RDA Investigation Data. Submittal date: 11/01/2001.

MO0111GSC01166.000. Field Maps for Windshield Surveys (With Annotations) for RDA Investigation ID: July 19, 2001 Residential Population Estimate 2001. Submittal date: 11/28/01.

MO0112YMP01015.001. 2000 Population Distribution Within the $84 \mathrm{~km}$ Radiological Monitoring Grid (2000 Census Geography). Submittal date: 12/06/2001.

\subsection{SOFTWARE}

CRWMS M\&O 2000c. Software Code: ARCINFO. V7.2.1. SGI Irix. 10033-7.2.1-00.

CRWMS M\&O 2000d. Software Baseline Request for LV-1999-006, ARCINFO V7.2.1. 100337.2.1-00. Las Vegas, Nevada: CRWMS M\&O. ACC: MOL.20000519.0018. 


\section{APPENDIX A \\ DOCUMENTATION OF THE USE OF COMMERCIAL OFF-THE-SHELF SOFTWARE}




\section{Documentation of the Use of Commercial Off-The-Shelf Software}

This documentation provides a detailed account of the use of COTS software in the preparation of this report. This documentation was developed per the direction of the responsible manager and in accordance with AP-SI.1Q, Software Management, and AP-SV.1Q, Control of the Electronic Management of Information.

Software identified for use in the preparation of this report

The software used to perform the steps detailed in this documentation is Microsoft Access 97 (YMP Product ID 53062-325-0832206-04078) which operates on Windows 95, Version 4.0. Data transmitted in an archived WinZip format that are contained on an Excel spreadsheet are unzipped to Microsoft Excel 97 SR-2 (YMP Product ID 53233-325-0832206-53984) which operates on Windows 95, Version 4.0. Arc/Info V7.2.1, STN: 10033-7.2.1-00 also is used in the preparation of data for this report. This GIS software was added to the M\&O Baseline of Qualified Software on February 10, 2000 (CRWMS M\&O 2000d), in accordance with APSI.1Q, Software Management. Arc/Info V7.2.1 was obtained from Configuration Management, run on a SGI-LV platform on workstation ID 110889, identified as the appropriate software for this application, and used within the range of the validation documentation.

\section{$\underline{\text { Location of files }}$}

The files created as a result of the steps detailed in this documentation are located on the $\mathrm{H}$ Drive of CPU 112178 under RadMonitoring 12001-RadMP. Folders in 2001-RadMP, and individual file names are identified in the body of the documentation.

Accuracy, completeness, and reproducibility of information

All files located on the H Drive of CPU 112178 are password protected. Any data file (such as an Excel spreadsheet) that is transmitted electronically, is archived (prior to being transmitted) using WinZip software. WinZip software uses a lossless compression scheme that maintains the integrity of the archived (zipped) file. All processes whereby data are placed into or modified within COTS software are described in a series of steps (Step 1, Step 2, etc.). Each step represents a stated objective. Within each step is a particular task, or series of tasks required to accomplish the objective, including any use of data inputs. Each task is identified by the generic name of the COTS software standard function used (e.g. Access Table Design, or Update Query). Once a particular task is completed, a written description of how the task was performed is provided. This description includes a copy of any software query language (SQL) generated by Access that shows how records are selected, grouped, and ordered when the standard function is used. Once all tasks (within a step) are completed, verification is provided to indicate that the stated objective was accomplished. Any new objects/products that are created (such as a table) are saved and identified in the documentation.

Any Access database table that is used to update information in another table contains a key (index) field(s). The key field in a table contains a distinctive set of data--which uniquely identifies each individual record in the table. If Access encounters duplicate values when trying to establish the index, an error message will occur and the index (key) will not be added. This key is the "one" component of the one-to-many relationship necessary to successfully match and update information from one table to another in Access without erroneous errors. 
Table names are underlined when mentioned in the text. For example, WS Housing dbt. Access database names also are underlined when mentioned in the text. For example, 2001-RadMP Investigation DB.mdb. Field names are bracketed when mentioned in the text. For example, [2001 Status].

\section{STEP 1}

Objective: Identify the location of each of the 15123 HUs in 00-01 RDA Investigation Data (MO0111GSC01153.000) with the Census 2000 tract and BG location, and the 84-km RadMP Grid, grid cell location (with the number of the grid "ring" and "slice").

Description of how this table was created and verification of the results: A new GIS coverage named RADHAUS3 (MO0111COV01120.000) was created in Arc/Info using 00-01 RDA Investigation Data (MO0111GSC01153.000) and Field Maps for Windshield Surveys (With Annotations) for RDA Investigation ID: July 19, 2001 Residential Population Estimate 2001 (MO0111GSC01166.000) as the sources. Other qualified GIS coverages identified for use in this application include the following:

RADGRIDU2 - MO0110COV01122.000 [84km RadMP Grid]

BLKGRP2KS - MO0107COV01066.000 [Bureau of the Census 2000 BG Data]

The Arc/Info IDENTITY function was used to compute the geometric intersection of the RADHAUS3 coverage with RADGRIDU2, and the RADHAUS3 coverage with the BLKGRP2KS to produce two feature attribute tables. These 2 tables were then combined into a single table, titled HUDATA, using the JOINITEM command in Arc/Info. In seven cases, where the same location was identified by two sources in 00-01 RDA Investigation Data, one of the duplicates was not included in HUDATA. The source table, 00-01 RDA Investigation Data, also contains one record that is not a HU location, and therefore, is not included in HUDATA. Four records are included in HUDATA that are not found in 00-01 RDA Investigation Data. These four are non-residential locations (identified by their location on a field map) that do not affect this analysis. HUDATA contains a total of 15119 records and the following fields:

$\begin{array}{ll}\text { [Housing Unit ID] } & \text { [Source] } \\ \text { [2000 Status] } & {[00 \text { Occupied HU] }} \\ \text { [00 Vacant HU } & {[00 \text { Persons in GQ] }} \\ \text { [2001 Status] } & {[01 \text { Occupied HU] }} \\ \text { [01 Vacant HU] } & {[01 \text { Persons in GQ] }} \\ \text { [Fipsstco] } & {[\text { Tract] }} \\ \text { [Group] } & {[\text { Stfid] }} \\ \text { [Radiological Monitoring Grid Ring] } & \text { [Radiological Monitoring Grid Slice] }\end{array}$

HUDATA was saved in an Excel spreadsheet and zipped using WinZip software. The size of the zipped file is $771 \mathrm{~KB}$. This file was transmitted electronically from Erika Provost, to Linda Roe on 11/2/01 in accordance with AP-SV.1Q, Control of the Management of Electronic Data. This was accomplished by transmitting the data in a WinZip format. The zipped file, HUDATA.zip, was detached and saved to the H Drive of CPU: 112178, which is password protected, in the 2001 AccessDB folder. HUDATA.zip was unzipped, creating an Excel spreadsheet, HUDATA.xls in the 2001 AccessDB folder.

\section{Step 2}

Objective: Import HUDATA.xls into the Access database 2001-RadMP Report DB.mdb, and make of copy of this table named 01 RadMP Report Data (save the original HUDATA for verification). Add a field named [Grid Cell], to 01 RadMP Report Data, and enter the grid cell 
number (a combination of the 84-km RadMP Grid "ring" and "slice" and numbers) associated with each HU location. Add another field named [Census Geography] to 01 RadMP Report Data, and enter the combined census tract and BG numbers into this field. Remove and save (for verification) all records where the $\mathrm{HU}$ is located outside the 84-km RadMP Grid, and all records where [status] is "6" (indicating an empty lot or dilapidated HU). Also delete any fields that are not required for this analysis.

Access task performed: Get external data/Import function

Description of the Access tasks performed and verification of the results: All fields in HUDATA.xls were imported. If Access encounters errors when trying to import a spreadsheet, an import errors table is automatically created that includes field names and row numbers that indicate which data have caused errors. No errors occurred while importing these data. Data from HUDATA.xls were successfully imported, resulting in an Access table named HUDATA that consists of 15119 records. A copy was made of HUDATA named 01 RadMP Report Data. A [Grid Cell] field was added to 01 RadMP Report Data, and the grid cell number associated with each HU location was entered. A total of 5037 records were removed from 01 RadMP

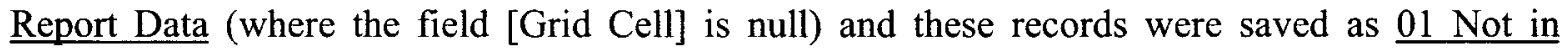
RadMP Report Data. Verification of the information entered in [Grid Cell] was done by visually checking a list of all combinations of the 3 applicable fields (shown below). No errors were found, and no records were found where the value in [Grid Cell] is null.

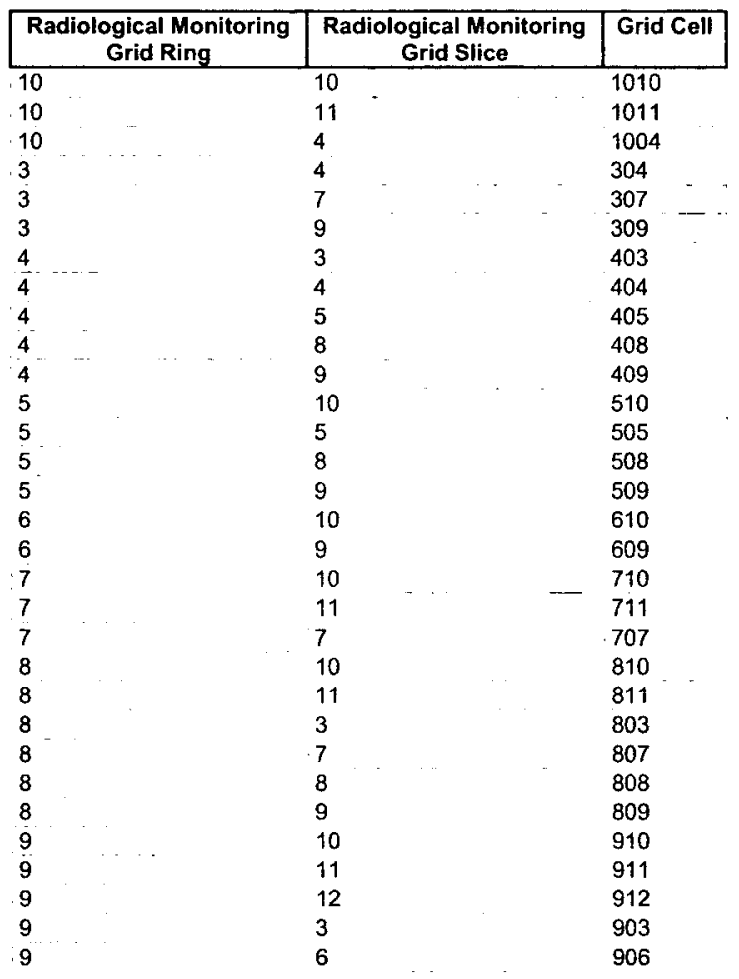

Another field, named [Census Geography], was added to 01 RadMP Report Data, and the combined census tract [Tract] and BG numbers [Group] were entered into this field. Verification of the information entered in [Census Geography] was done by visually checking a list of the 19 combinations of the 3 fields (shown below). No errors were found. 


\begin{tabular}{|c|c|c|}
\hline Tract & Group & Census Geography \\
\hline 000500 & 2 & Tract 5 BG 2 \\
\hline 000700 & 1 & Tract 7 BG 1 \\
\hline 005817 & 1 & Tract $58.17 \mathrm{BG} 1$ \\
\hline 005818 & 1 & Tract $58.18 \mathrm{BG} 1$ \\
\hline 005902 & 9 & Tract 59.02 BG 9 \\
\hline 980300 & 1 & Tract 9803 BG 1 \\
\hline 980300 & 2 & Tract 9803 BG 2 \\
\hline 980300 & 3 & Tract 9803 BG 3 \\
\hline 980401 & 1 & Tract $9804.018 \mathrm{BG} 1$ \\
\hline 980401 & 2 & Tract 9804.01 BG 2 \\
\hline 980402 & 1 & Tract 9804.02 BG 1 \\
\hline 980402 & 2 & Tract 9804.02 BG 2 \\
\hline 980402 & 3 & Tract 9804.02 BG 3 \\
\hline 980403 & 1 & Tract 9804.03 BG 1 \\
\hline 980403 & 2 & Tract 9804.03 BG 2 \\
\hline 980404 & 1 & Tract 9804.04 BG 1 \\
\hline 980404 & 2 & Tract 9804.04 BG 2 \\
\hline 980405 & 1 & Tract 9804.05 BG 1 \\
\hline 980406 & 1 & Tract $9804.06 \mathrm{BG} 1$ \\
\hline
\end{tabular}

A total of 27 records were removed where [2000 Status] and [2001 Status] are both " 6 " and these records were added to 01 Not in RadMP Report. And finally, the following fields (that are not used in this report) were deleted: [Fipsstco], [Tract], [Group], [Stfid], [Radiological Monitoring Grid Ring], and [Radiological Monitoring Grid Slice]. The total number of records in 01 RadMP Report Data (10055) and 01 Not in RadMP Report (5064) is equal to 15119, from HUDATA.

Tables created in Access:

01 RadMP Report Data

01 Not in RadMP Report

\section{STEP 3}

\section{Objective:}

Create a new table in the Access database 2001-RadMP Report DB.mdb that contains a record for each census BG that is found within the study area, and includes the name of the county and state in which the BG is located and data from the four census 2000 tables listed below:

1) P1. TOTAL POPULATION [1] - Universe: Total population

2) P15. HOUSEHOLDS [1] - Universe: Households

3) P17. AVERAGE HOUSEHOLD SIZE [1] - Universe: Households

4) P37. GROUP QUARTERS POPULATION BY GROUP QUARTERS TYPE [9] -

Universe: Population in group quarters

Access task performed: Table Design

Data entry and verification of results: A new table named Census $2000 \mathrm{dbt}$ was created in the Access database 2001-RadMP Report DB.mdb that contains 19 census BGs and data from the 4 tables listed above. These data were acquired from the Census 2000 Summary File 1 (SF 1) 100Percent Data (Bureau of the Census 2001). Verification was performed by visually comparing the contents of this table (shown below) to the print outs of the original census tables. No errors were found. 


\begin{tabular}{|c|c|c|c|c|c|}
\hline Census Geography & County and State & $\begin{array}{l}\text { P1\# TOTAL } \\
\text { POPULATION }\end{array}$ & P15\# HOUSEHOLDS & $\begin{array}{l}\text { P17\# AVERAGE } \\
\text { HOUSEHOLD SIZE }\end{array}$ & $\begin{array}{c}\text { P37\# GROUP } \\
\text { QUARTERS } \\
\text { POPULATION BY } \\
\text { GROUP QUARTERS } \\
\text { TYPE } \\
\end{array}$ \\
\hline Tract 5 BG 2 & Inyo County, CA & 813 & 377 & 2.16 & 0 \\
\hline Tract 7 BG 1 . & Inyo County, CA & 638 & 350 & 1.82 & 0 \\
\hline Tract $58.17 \mathrm{BG} 1$ & Clark County, NV & 1058 & 439 & 2.34 & 29 \\
\hline Tract 58.18 BG 1 & Clark County, NV & 3017 & 490 & 2.56 & 1765 \\
\hline Tract 59.02 BG 9 & Clark County, NV & 62 & 42 & 1.48 & 0 \\
\hline Tract 9804.01 BG 1 & Nye County, NV & 1941 & 838 & 2.29 & 24 \\
\hline Tract 9804.01 BG 2 & Nye County, NV & 1952 & 799 & 2.41 & 23 \\
\hline Tract $9804.02 \mathrm{BG} 1$ & Nye County, NV & 1285 & 514 & 2.50 & 0 \\
\hline Tract 9804.02 BG 2 & Nye County, NV & 1310 & 529 & 2.48 & 0 \\
\hline Tract 9804.02 BG 3 & Nye County, NV & 1629 & 735 & 2.22 & 0 \\
\hline Tract 9804.03 BG 1 & Nye County, NV & 2693 & 1019 & 2.63 & 11 \\
\hline Tract $9804.03 \mathrm{BG} 2$ & Nye County, NV & 1662 & 735 & 2.26 & 0 \\
\hline Tract 9804.04 BG 1 & Nye County, NV & 3141 & 1358 & 2.31 & 0 \\
\hline Tract 9804.04 BG 2 & Nye County, NV & 1260 & 518 & 2.43 & 0 \\
\hline Tract $9804.05 \mathrm{BG} 1$ & Nye County, NV & 2236 & 908 & 2.46 & 4 \\
\hline Tract 9804.06 BG 1 & Nye County, NV & 4525 & 1760 & 2.57 & 0 \\
\hline Tract 9803 BG 1 & Nye County, NV & 655 & 304 & 2.15 & 0 \\
\hline Tract 9803 BG 2 & Nye County, NV & 518 & 241 & 2.15 & 0 \\
\hline Tract 9803 BG 3 & Nye County, NV & 1176 & 429 & 2.74 & 0 \\
\hline
\end{tabular}

Table created in Access: Census $2000 \mathrm{dbt}$

\section{STEP 4}

Objective: Add two new fields [P17\# AVERAGE HOUSEHOLD SIZE] and [County and State] to 01 RadMP Report Data and update these fields with the value from [P17\# AVERAGE HOUSEHOLD SIZE] and [County and State] in Census $2000 \mathrm{dbt}$ for each HU record.

$\mathbf{1}^{\text {st }}$ Access task performed: Table design

$2^{\text {nd }}$ Access task performed: Update query

$2^{\text {nd }}$ task, query name: UDQ Step 4

Computer-generated SQL expression of $2^{\text {nd }}$ task, query commands: UPDATE [Census 2000 dbt] INNER JOIN [01 RadMP Report Data] ON [Census $2000 \mathrm{dbt}$ ].[Census Geography] = [01 RadMP Report Data].[Census Geography] SET [01 RadMP Report Data].[County and State] = [Census 2000 dbt].[County and State], [01 RadMP Report Data].[P17\# AVERAGE HOUSEHOLD SIZE] = [Census $2000 \mathrm{dbt}$.[P17\# AVERAGE HOUSEHOLD SIZE];

Description of the Access tasks performed and verification of the results: In the $1^{\text {st }}$ Access task, two new fields called [P17\# AVERAGE HOUSEHOLD SIZE] and [County and State] were added to 01 RadMP Report Data (in table design). In the $2^{\text {nd }}$ Access task, 10055 records in 01 RadMP Report Data were updated with the value in [P17\# AVERAGE HOUSEHOLD SIZE] and [County and State] from the table Census $2000 \mathrm{dbt}$. Verification was performed by comparing the value of P17\# AVERAGE HOUSEHOLD SIZE and the name of the county and state in the two tables (by census geography). No errors were found.

\section{STEP 5}

\section{Objective:}

Create a new table in the Access database 2001-RadMP Report DB.mdb named Area Names dbt that includes [Grid Cell] and [County and State] information (the same fields found in 01 RadMP Report Data), and [Area], [Town], and [Grid Cell and Town]. Then add the fields [Area], [Town], and [Grid Cell and Town] to 01 RadMP Report Data and update these 3 fields with the information in Area Names dbt. 
$1^{\text {st }}$ Access task performed: Table design and data entry

$2^{\text {nd }}$ Access task performed: Update Query

$2^{\text {nd }}$ task, query name: UDQ Step 5

Computer-generated SQL expression of $2^{\text {nd }}$ task, query commands: UPDATE [Area Names dbt] INNER JOIN [01 RadMP Report Data] ON ([Area Names dbt].[Grid Cell] $=[01$ RadMP Report Data].[Grid Cell]) AND ([Area Names dbt].[County and State] $=[01$ RadMP Report Data].[County and State]) SET [01 RadMP Report Data].Area = [Area Names dbt].[Area], [01 RadMP Report Data].Town = [Area Names dbt].[Town], [01 RadMP Report Data].[Grid Cell and Town $]=[$ Area Names dbt].[Grid Cell and Town];

Data entry and verification of results: A new table Area Names dbt was created in the Access database 2001-RadMP Report DB.mdb that contains 29 records. Two (key) fields [Grid Cell] and [County and State] make up the unique identifier for each record. Verification of the information entered in this table was performed by visually comparing the contents of this table (shown below) to a map of the study area (such as Figure 1 in this report). No errors were found.

\begin{tabular}{|c|c|c|c|c|}
\hline $\begin{array}{r}\text { Grid Cell } \\
\text { (key field) }\end{array}$ & \begin{tabular}{|c|}
$\begin{array}{c}\text { County and State } \\
\text { (key field) }\end{array}$ \\
\end{tabular} & Area & Town & Grid Cell and Town \\
\hline 1010 & Inyo County, CA & Death Valley Area & Stewart Valley, CA & Grid Cell 1010 (Stewart Valley, CA) \\
\hline 1011 & Clark County, NV & Indian Springs & Cold Creek & Grid Cell 1011 (Cold Creek) \\
\hline $304^{-}$ & Nye County, NV & Beatty Area & Hot Springs & Grid Cell 304 (Hot Springs) \\
\hline 309 & Nye County, NV & Amargosa Valley Area & Lathrop Wells & Grid Cell 309 (Lathrop Wells) \\
\hline 405 & Nye County, NV & Beatty Area & Beatty & Grid Cell 405 (Beatty) \\
\hline 408 & Nye County, NV & Amargosa Valley Area & Amargosa Valley & Grid Cell 408 (Amargosa Valley) \\
\hline 409 & Nye County, NV & Amargosa Valley Area & Amargosa Valley & Grid Cell 409 (Amargosa Valley) \\
\hline 505 & Nye County, NV & Beatty Area & Rhyolite & Grid Cell 505 (Rhyolite) \\
\hline 508 & Nye County, NV & Amargosa Valley Area & Amargosa Valley & Grid Cell 508 (Amargosa Valley) \\
\hline 509 & Nye County, NV & Amargosa Valley Area & Amargosa Valley & Grid Cell 509 (Amargosa Valley) \\
\hline 710 & Nye County, NV & Amargosa Valley Area & Ash Meadows & Grid Cell 710 (Ash Meadows) \\
\hline 711 & Nye County, NV & Pahrump Area & Johnnie & Grid Cell 711 (Johnnie) \\
\hline 803 & Nye County, NV & Beatty Area & Scotty's Junction & Grid Cell 803 (Scotty's Junction) \\
\hline 807 & Inyo County, CA & Death Valley Area & Timbisha & Grid Cell 807 (Timbisha) \\
\hline 808 & Inyo County, CA & Death Valley Area & Ryan & Grid Cell 808 (Ryan) \\
\hline 809 & Inyo County, CA & Death Valley Area & Death Valley Junction & Grid Cell 809 (Death Valley Junction) \\
\hline 810 & Nye County, NV & Pahrump Area & Pahrump & Grid Cell 810 (Pahrump) \\
\hline 903 & Nye County, NV & Beatty Area & Scotty's Junction & Grid Cell 903 (Scotty's Junction) \\
\hline 906 & Inyo County, CA & Death Valley Area & Stovepipe Wells & Grid Cell 906 (Stovepipe Wells) \\
\hline 910 & Nye County, NV & Pahrump Area & Pahrump & Grid Cell 910 (Pahrump) \\
\hline 912 & Clark County, NV & Indian Springs & Indian Springs \& Cactus Springs & Grid Cell 912 (Indian Springs \& Cactus Springs) \\
\hline
\end{tabular}

The fields [Area], [Town], and [Grid Cell and Town] were added to 01 RadMP Report Data and these 3 fields were updated in 10055 records with the information in Area Names dbt.

\section{STEP 6}

Objective: Add three new records to 01 RadMP Report Data and enter applicable data for the three census blocks identified as having a group quarters population. Then add two new fields [00 HUxPPH+GQ] and [01 HUxPPH+GQ] to 01 RadMP Report Data. Update [00 $\mathrm{HUxPPH}+\mathrm{GQ}]$ with the value in [00 Occupied HU] multiplied by [P17\# AVERAGE HOUSEHOLD SIZE] plus [00 Persons in GQ]. Update [01 HUxPPH+GQ] with the value in [01 Occupied HU] multiplied by [P17\# AVERAGE HOUSEHOLD SIZE] plus [01 Persons in GQ]. And finally, create a new table in the Access database 2001-RadMP Report DB.mdb that shows 
total resident population by state, county, area, and grid cell. These data are for use in Table 1 of the report.

$1^{\text {st }}$ Access task performed: Data entry

$2^{\text {nd }}$ Access task performed: Table design

$3^{\text {rd }}$ Access task performed: Update query

$3^{\text {rd }}$ task, query name: UDQ Step 6 Task 3

$4^{\text {th }}$ Access task performed: Update query

$4^{\text {th }}$ task, query name: UDQ Step 6 Task 4

$5^{\text {th }}$ Access task performed: Make table query

$5^{\text {th }}$ task, query name: MTQ Report Table 1

Computer-generated SQL expression of $3^{\text {rd }}$ task, query commands: UPDATE [01 RadMP

Report Data] SET [01 RadMP Report Data].[00 HUxPPH+GQ] = [01 RadMP Report Data]![00 Occupied HU]*[01 RadMP Report Data]![P17\# AVERAGE HOUSEHOLD SIZE]+[01 RadMP Report Data]![00 Persons in GQ];

Computer-generated SQL expression of $4^{\text {th }}$ task, query commands: UPDATE [01 RadMP Report Data] SET [01 RadMP Report Data].[01 HUxPPH+GQ] = [01 RadMP Report Data]![01 Occupied HU]*[01 RadMP Report Data]![P17\# AVERAGE HOUSEHOLD SIZE]+[01 RadMP Report Data]![01 Persons in GQ];

Computer-generated SQL expression of $\mathbf{5}^{\text {th }}$ task, query commands: SELECT [01 RadMP Report Data].[County and State], [01 RadMP Report Data].Area, [01 RadMP Report Data].[Grid Cell and Town], Sum([01 RadMP Report Data].[00 HUxPPH+GQ]) AS [SumOf00 HUxPPH+GQ], Sum([01 RadMP Report Data].[01 HUxPPH+GQ]) AS [SumOf01 HUxPPH+GQ] INTO [Report Table 1]FROM [01 RadMP Report Data]GROUP BY [01 RadMP Report Data].[County and State], [01 RadMP Report Data].Area, [01 RadMP Report Data].[Grid Cell and Town], [01 RadMP Report Data].[Report Order] ORDER BY [01 RadMP Report Data].[Report Order];

Description of the Access tasks performed and verification of the results: In the $1^{\text {st }}$ task, three new records were added to 01 RadMP Report Data $(10055+3=10058)$ for the three census blocks identified as having a group quarters population, and the following data were entered:

\begin{tabular}{|c|c|c|c|c|c|c|c|c|c|c|c|c|c|c|}
\hline \begin{tabular}{|l|} 
Housing \\
Unit ID
\end{tabular} & Source & $\begin{array}{c}00 \\
\text { Occupie } \\
\text { d HU }\end{array}$ & $\begin{array}{l}2000 \\
\text { Status }\end{array}$ & \begin{tabular}{|c|}
00 \\
Persons in \\
GQ
\end{tabular} & $\begin{array}{l}2001 \\
\text { Status }\end{array}$ & $\begin{array}{c}01 \\
\text { Occupied } \\
\text { HU }\end{array}$ & $\begin{array}{c}01 \\
\text { Persons in } \\
\text { GQ }\end{array}$ & $\begin{array}{l}\text { Grid } \\
\text { Cell }\end{array}$ & $\begin{array}{c}\text { P17\# } \\
\text { AVERAGE } \\
\text { HOUSEHOLD } \\
\text { SIZE }\end{array}$ & $\begin{array}{c}\text { Census } \\
\text { Geography }\end{array}$ & $\begin{array}{c}\text { County } \\
\text { and State }\end{array}$ & Area & Town & $\begin{array}{l}\text { Grid Cell } \\
\text { and Town }\end{array}$ \\
\hline $\begin{array}{l}\text { Block } \\
1104\end{array}$ & Census & 0 & 8 & 24 & 8 & 0 & 24 & 1010 & 2.29 & $\begin{array}{l}\text { Tract } \\
9804.01 \\
\text { BG } 1\end{array}$ & $\begin{array}{l}\text { Nye } \\
\text { County, } \\
\text { NV }\end{array}$ & $\begin{array}{l}\text { Pahrump } \\
\text { Area }\end{array}$ & Pahrump & $\begin{array}{l}\text { Grid Cell } \\
1010 \\
\text { (Pahrump) }\end{array}$ \\
\hline $\begin{array}{l}\text { Block } \\
2000\end{array}$ & Census & 0 & 8 & 23 & 8 & 0 & 23 & 910 & 2.41 & $\begin{array}{l}\text { Tract } \\
9804.01 \\
\text { BG } 2\end{array}$ & $\begin{array}{l}\text { Nye } \\
\text { County, } \\
\text { NV }\end{array}$ & $\begin{array}{l}\text { Pahrump } \\
\text { Area }\end{array}$ & Pahrump & $\begin{array}{l}\text { Grid Cell } \\
910 \\
\text { (Pahrump) }\end{array}$ \\
\hline $\begin{array}{l}\text { Block } \\
1145\end{array}$ & Census & 0 & 8 & 11 & 8 & 0 & 11 & 1010 & 2.63 & $\begin{array}{l}\text { Tract } \\
9804.03 \\
\text { BG } 1\end{array}$ & $\begin{array}{l}\text { Nye } \\
\text { County, } \\
\text { NV }\end{array}$ & $\begin{array}{l}\text { Pahrump } \\
\text { Area }\end{array}$ & Pahrump & $\begin{array}{l}\text { Grid Celi } \\
1010 \\
\text { (Pahrump) }\end{array}$ \\
\hline
\end{tabular}

These data were acquired from the Census 2000 Summary File 1 (SF 1) 100-Percent Data (Bureau of the Census 2001). Verification was performed by visually comparing the contents of this table (shown below) to the print outs of the original census tables. No errors were found. In the $2^{\text {nd }}$ task, two new fields [00 HUxPPH+GQ] and [01 HUxPPH+GQ] were added in table design. In the $3^{\text {rd }}$ task, [00 HUxPPH+GQ] was updated with the value in [00 Occupied HU] multiplied by [P17\# AVERAGE HOUSEHOLD SIZE] plus [00 Persons in GQ]. In the $4^{\text {th }}$ task, [01 HUxPPH+GQ] was updated with the value in [01 Occupied HU] multiplied by [P17\# AVERAGE HOUSEHOLD SIZE] plus [01 Persons in GQ]. The results of task 3 and task 4, were verified by visually checking a list of all combinations of the 8 applicable fields (shown below). The results were checked by hand calculations. No errors were found. 


\begin{tabular}{|c|c|c|c|c|c|c|c|}
\hline Grid Cell and Town & $\begin{array}{c}\text { AVERAGE } \\
\text { HOUSEHOLD } \\
\text { SIZE }\end{array}$ & $\begin{array}{c}2000 \text { Total } \\
\text { Occupied HU }\end{array}$ & $\begin{array}{c}2000 \text { Total } \\
\text { Persons in } \\
\text { GQ }\end{array}$ & $\begin{array}{c}2000 \text { Total } \\
\text { HUXPPH+GQ }\end{array}$ & 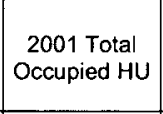 & $\begin{array}{c}2001 \text { Total } \\
\text { Persons in } \\
\text { GQ }\end{array}$ & $\begin{array}{c}2001 \text { Total } \\
\text { HUXPPH+GQ }\end{array}$ \\
\hline Grid Cell 309 (Lathrop Wells) & 2.74 & 9 & 0 & 24.66 & 5 & 0 & 13.70 \\
\hline Grid Cell 408 (Ämargosa Valley) & 2.74 & 144 & 0 & 394.56 & 113 & 0 & 309.62 \\
\hline Grid Cell 409 (Amargosa Valley) & 2.74 & 104 & 0 & 284.96 & 103 & 0 & 282.22 \\
\hline Grid Cell 508 (Amargosa Valley) & 2.74 & 28 & 0 & 76.72 & 22 & 0 & 60.28 \\
\hline Grid Cell 509 (Amargosa Valley) & 2.74 & 215 & 0 & 589.10 & 169 & 0 & 463.06 \\
\hline Grid Cell 510 (Crystal) & 2.29 & 11 & 0 & 25.19 & 9 & 0 & 20.61 \\
\hline Grid Cell 510 (Crystal) & 2.74 & 0 & 0 & 0.00 & 1 & 0 & 2.74 \\
\hline Grid Cell 610 (Crystal) & 2.29 & 49 & 0 & 112.21 & 51 & 0 & 116.79 \\
\hline Grid Cell 610 (Crystal) & 2.74 & 2 & 0 & 5.48 & 2 & 0) & 5.48 \\
\hline Grid Cell 609 (Stateline) & 2.74 & 72 & 0 & 197.28 & 40 & 0 & 109.60 \\
\hline Grid Cell 710 (Ash Meadows) & 2.74 & 10 & 0 & 27.40 & 6 & 0 & 16.44 \\
\hline Grid Cell 304 (Hot Springs) & 2.15 & 14 & 0 & 30.10 & 20 & of & 43.00 \\
\hline Grid Cell 403 (Hot Springs) & 2.15 & 11 & 0 & 23.65 & 12 & 0 & 25.80 \\
\hline Grid Cell 404 (Beatty) & 2.15 & 379 & 0 & 814.85 & 319 & o & 685.85 \\
\hline Grid Cell 405 (Beatty) & 2.15 & 233 & 0 & 500.95 & 190 & 0 & 408.50 \\
\hline Grid Cell 505 (Rhyolite) & 2.15 & 2 & 0 & 4.30 & 4 & 0 & 8.60 \\
\hline Grid Cell 803 (Scotty's Junction) & 2.15 & 1 & 0 & 2.15 & 0 & 0 & 0.00 \\
\hline Grid Cell 903 (Scotty's Junction) & 2.15 & 10 & 0 & 21.50 & 11 & 0 & 23.65 \\
\hline Grid Cell 711 (Johnnie) & 2.29 & 9 & 0 & 20.61 & 9 & 0 & 20.61 \\
\hline Grid Cell 810 (Pahrump) & 2.29 & 19 & 0 & 43.51 & 22 & 0 & 50.38 \\
\hline Grid Cell 811 (Pahrump) & 2.29 & 0 & 0 & 0.00 & 1 & 0 & 2.29 \\
\hline Grid Cell 910 (Pahrump) & 2.26 & 287 & 0 & 648.62 & 315 & 0 & 711.90 \\
\hline Grid Cell 910 (Pahrump) & 2.29 & 483 & 0 & 1106.07 & 559 & 0 & 1280.11 \\
\hline Grid Cell 910 (Pahrump) & 2.41 & 810 & 23 & 1975.10 & 880 & 23 & 2143.80 \\
\hline Grid Cell 910 (Pahrump) & 2.50 & 351 & 0 & 877.50 & 358 & 0 & 895.00 \\
\hline Grid Cell 910 (Pahrump) & 2.63 & 212 & 0 & 557.56 & 241 & 0 & 633.83 \\
\hline Grid Cell 911 (Pahrump) & 2.29 & 0 & 0 & 0.00 & 1 & 0 & 2.29 \\
\hline Grid Cell 1010 (Pahrump) & 2.22 & 621 & 0 & 1378.62 & 653 & 0 & 1449.66 \\
\hline Grid Cell 1010 (Pahrump) & 2.26 & 406 & 0 & 917.56 & 414 & 0 & 935.64 \\
\hline Grid Cell 1010 (Pahrump) & 2.29 & 81 & 24 & 209.49 & 105 & 24 & 264.45 \\
\hline Grid Cell 1010 (Pahrump) & 2.31 & 1276 & 0 & 2947.56 & 1414 & 0 & 3266.34 \\
\hline Grid Cell 1010 (Pahrump) & 2.43 & 466 & 0 & 1132.38 & 556 & 0 & 1351.08 \\
\hline Grid Cell 1010 (Pahrump) & 2.46 & 26 & 0 & 63.96 & 24 & 0 & 59.04 \\
\hline Grid Cell 1010 (Pahrump) & $2 . \overline{48}$ & 494 & 0 & 1225.12 & 539 & 0 & 1336.72 \\
\hline Grid Cell 1010 (Pahrump) & 2.50 & 173 & 0 & 432.50 & 185 & 0 & 462.50 \\
\hline Grid Cell 1010 (Pahrump) & 2.57 & 7 & 0 & 17.99 & 8 & 0 & 20.56 \\
\hline Grid Cell 1010 (Pahrump) & 2.63 & 798 & 11 & 2109.74 & 874 & 11 & 2309.62 \\
\hline $\begin{array}{l}\text { Grid Cell } 912 \text { (Indian Springs \& Cactus } \\
\text { Springs) }\end{array}$ & 1.48 & 38 & 0 & 56.24 & 47 & 0 & 69.56 \\
\hline $\begin{array}{l}\text { Grid Cell } 912 \text { (Indian Springs \& Cactus } \\
\text { Springs) }\end{array}$ & 2.56 & 474 & 0 & 1213.44 & 488 & 0 & 1249.28 \\
\hline Grid Cell 1011 (Cold Creek) & 2.34 & 70 & 0 & 163.80 & 65 & 0 & 152.10 \\
\hline Grid Cell 1011 (Cold Creek) & 2.56 & 7 & 0 & 17.92 & 4 & 0 & 10.24 \\
\hline Grid Cell 707 (Furnace Creek) & 1.82 & 168 & 98 & 403.76 & 64 & 346 & 462.48 \\
\hline Grid Cell 807 (Timbisha) & 1.82 & 10 & 0 & 18.20 & 10 & 0 & 18.20 \\
\hline Grid Cell 808 (Ryan) & 1.82 & 1 & 0 & 1.82 & 1 & 0 & 1.82 \\
\hline Grid Cell 809 (Death Valley Junction) & 1.82 & $\overline{6}$ & 0 & 10.92 & 1 & 0 & 1.82 \\
\hline Grid Cell 906 (Stovepipe Wells) & 1.82 & 29 & 0 & 52.78 & 0 & 68 & 68.00 \\
\hline Grid Cell 1004 (Scotty's Castle) & 2.16 & 2 & 3 & 7.32 & 0 & 7 & 7.00 \\
\hline Grid Cell 1010 (Stewart Valley, CA) & 1.82 & 7 & 0 & 12.74 & 7 & 0 & 12.74 \\
\hline
\end{tabular}


And finally, in task 5, a query was run that created the Access table, Report Table 1 (shown below), that is the source of the information provided in Table 1, in Section 3 of this report.

\begin{tabular}{|c|c|c|c|c|}
\hline County and State & Area & Grid Cell and Town & SumOf00 HUxPPH+GQ & SumOf01 HUXPPH+GQ \\
\hline Nye County, NV & Amargosa Valley Area & $\begin{array}{l}\text { Grid Cell } 309 \text { (Lathrop } \\
\text { Wells) }\end{array}$ & 24.66 & 13.7 \\
\hline Nye County, NV & Amargosa Valley Area & $\begin{array}{l}\text { Grid Cell } 408 \text { (Amargosa } \\
\text { Valley) }\end{array}$ & 394.560000000001 & 309.620000000001 \\
\hline Nye County, NV & Amargosa Valley Area & $\begin{array}{l}\text { Grid Cell } 409 \text { (Amargosa } \\
\text { Valley) }\end{array}$ & 284.96 & 282.22 \\
\hline Nye County, NV & Amargosa Valley Area & $\begin{array}{l}\text { Grid Cell } 508 \text { (Amargosa } \\
\text { Valley) }\end{array}$ & 76.72 & 60.28 \\
\hline Nye County, NV & Amargosa Valley Area & $\begin{array}{l}\text { Grid Cell } 509 \text { (Amargosa } \\
\text { Valley) }\end{array}$ & 589.100000000001 & 463.060000000001 \\
\hline Nye County, NV & Amargosa Valley Area & Grid Cell 510 (Crystal) & 25.19 & 23.35 \\
\hline Nye County, NV & Amargosa Valley Area & Grid Cell 610 (Crystal) & 117.69 & 122.27 \\
\hline Nye County, NV & Amargosa Valley Area & Grid Cell 609 (Stateline) & 197.28 & 109.6 \\
\hline Nye County, NV & Amargosa Valley Area & $\begin{array}{l}\text { Grid Cell } 710 \text { (Ash } \\
\text { Meadows) }\end{array}$ & 27.4 & 16.44 \\
\hline Nye County, NV & Beatty Area & $\begin{array}{l}\text { Grid Cell } 304 \text { (Hot } \\
\text { Springs) }\end{array}$ & 30.1 & 43 \\
\hline Nye County, NV & Beatty Area & $\begin{array}{l}\text { Grid Cell } 403 \text { (Hot } \\
\text { Springs) }\end{array}$ & 23.65 & 25.8 \\
\hline Nye County, NV & Beatty Area & Grid Cell 404 (Beatty) & 814.849999999995 & 685.849999999996 \\
\hline Nye County, NV & Beatty Area & Grid Cell 405 (Beatty) & 500.949999999998 & 408.499999999999 \\
\hline Nye County, NV & Beatty Area & Grid Cell 505 (Rhyolite) & 4.3 & 8.6 \\
\hline Nye County, NV & Beatty Area & $\begin{array}{l}\text { Grid Cell } 803 \text { (Scotty's } \\
\text { Junction) }\end{array}$ & 2.15 & 0 \\
\hline Nye County, NV & Beatty Area & $\begin{array}{l}\text { Grid Cell } 903 \text { (Scotty's } \\
\text { Junction) }\end{array}$ & 21.5 & 23.65 \\
\hline Nye County, NV & Pahrump Area & Grid Cell 711 (Johnnie) & 20.61 & 20.61 \\
\hline Nye County, NV & Pahrump Area & Grid Cell 810 (Pahrump) & 43.51 & 50.38 \\
\hline Nye County, NV & Pahrump Area & Grid Cell 811 (Pahrump) & 0 & 2.29 \\
\hline Nye County, NV & Pahrump Area & Grid Cell 910 (Pahrump) & 5164.85000000006 & 5664.64000000005 \\
\hline Nye County, NV & Pahrump Area & Grid Cell 911 (Pahrump) & 0 & 2.29 \\
\hline Nye County, NV & Pahrump Area & Grid Cell 1010 (Pahrump) & 10434.9200000002 & 11455.6100000001 \\
\hline Clark County, NV & Indian Springs & $\begin{array}{l}\text { Grid Cell } 912 \text { (Indian } \\
\text { Springs \& Cactus Springs) }\end{array}$ & 1269.67999999999 & 1318.83999999999 \\
\hline Clark County, NV & Indian Springs & $\begin{array}{l}\text { Grid Cell } 1011 \text { (Cold } \\
\text { Creek) }\end{array}$ & 181.72 & 162.34 \\
\hline Inyo County, CA & Death Valley Area & $\begin{array}{l}\text { Grid Cell } 707 \text { (Furnace } \\
\text { Creek) }\end{array}$ & 403.759999999999 & 462.48 \\
\hline Inyo County, CA & Death Valley Area & Grid Cell 807 (Timbisha) & 18.2 & 18.2 \\
\hline Inyo County, CA & Death Valley Area & Grid Cell 808 (Ryan) & 1.82 & 1.82 \\
\hline inyo County, CA & Death Valley Area & $\begin{array}{l}\text { Grid Cell } 809 \text { (Death } \\
\text { Valley Junction) }\end{array}$ & 10.92 & 1.82 \\
\hline Inyo County, CA & Death Valley Area & $\begin{array}{l}\text { Grid Cell } 906 \text { (Stovepipe } \\
\text { Wells) }\end{array}$ & 52.78 & 68 \\
\hline Inyo County, CA & Death Valley Area & $\begin{array}{l}\text { Grid Cell } 1004 \text { (Scotty's } \\
\text { Castle) }\end{array}$ & 7.32 & 7 \\
\hline Inyo County, CA & Death Valley Area & $\begin{array}{l}\text { Grid Cell } 1010 \text { (Stewart } \\
\text { Valley, CA) }\end{array}$ & 12.74 & 12.74 \\
\hline
\end{tabular}

Table created in Access: $\underline{\text { Report Table } 1}$ 